\title{
Hydrodynamics in the Gulf of Aigues-Mortes, NW Mediterranean Sea: In situ and modelling data
}

\author{
Yann Leredde ${ }^{\mathrm{a}, *}$, Cléa Denamiel ${ }^{\mathrm{a}}$, Elena Brambilla ${ }^{\mathrm{a}}$, Christine Lauer-Leredde ${ }^{\mathrm{a}}$, \\ Frédéric Bouchette ${ }^{\mathrm{a}}$, Patrick Marsaleix ${ }^{\mathrm{b}}$ \\ a Géosciences Montpellier-UMR CNRS-UM2 5243, Université Montpellier 2, CC. 60, place E Bataillon, 34095 Montpellier cedex 5, France
b Laboratoire d'Aérologie, UMR 5560 UPS-CNRS, Pôle d'Océanographie Côtière, 14, Avenue Edouard Belin, 31400 Toulouse, France
}

The Gulf of Aigues-Mortes (NW Mediterranean Sea) is a midshelf zone whose scale is an intermediate between the nearshore scale $(0-10 \mathrm{~m}$ depth) and the coastal scale (including the whole continental shelf). Its hydrodynamics is investigated for the first time. ADCP, CTD and thermosalinograph data were collected during three short cruises (HYGAM; March 6-7, 20-21, April 5-6, 2005). They were scheduled approximately every 15 days to sample the gulf circulation under different weather conditions. Moreover, the cruise data were used to validate the Symphonie model, a 3D primitive equations circulation model. The circulation features displayed by in situ data were well reproduced by Symphonie. A downscaling modelling approach was implemented, the largest scale being obtained by the replay of the MFSTEP regional model of the North-Western Mediterranean Sea.

The analysis, closely coupling in situ measurements and model results, provides information that would not have been obtained using data separately. The great variability of the oceanic circulation at this scale is well evidenced. Winds are the main forces, not only locally but also at a larger scale. North winds generate coherent structures interacting with the general Mediterranean circulation. The explanation of the induced currents is then not straightforward, some of them being, for example, northward. South and southeast winds reinforce the sloping surface, the latter allowing the geostrophic equilibrium with longshore currents. This study, focused on the end of winter 2004-2005, also enhances the heat fluxes from offshore to nearshore, as well as the initiation of shelf dense waters.

The knowledge of the midshelf oceanic circulation is then applied to run a numerical experiment which describes both the dispersion of a fictive contaminant from a point $\mathrm{S}$ (at the centre of the GAM), and evaluates the risk of contamination of the beaches along the GAM shores.

Keywords: Current data; Modelling; Shelf dynamics; Wind-induced currents; Sewage dispersion

\section{Introduction}

\footnotetext{
*Corresponding author. Tel.: + 33467143630 ; fax: +33467143642 .

E-mail address: leredde@gm.univ-montp2.fr (Y. Leredde).
}

The Gulf of Aigues-Mortes (GAM) is located in the Northwestern Mediterranean Sea (Fig. 1). This zone is the northern part of the Gulf of Lion (GoL) 


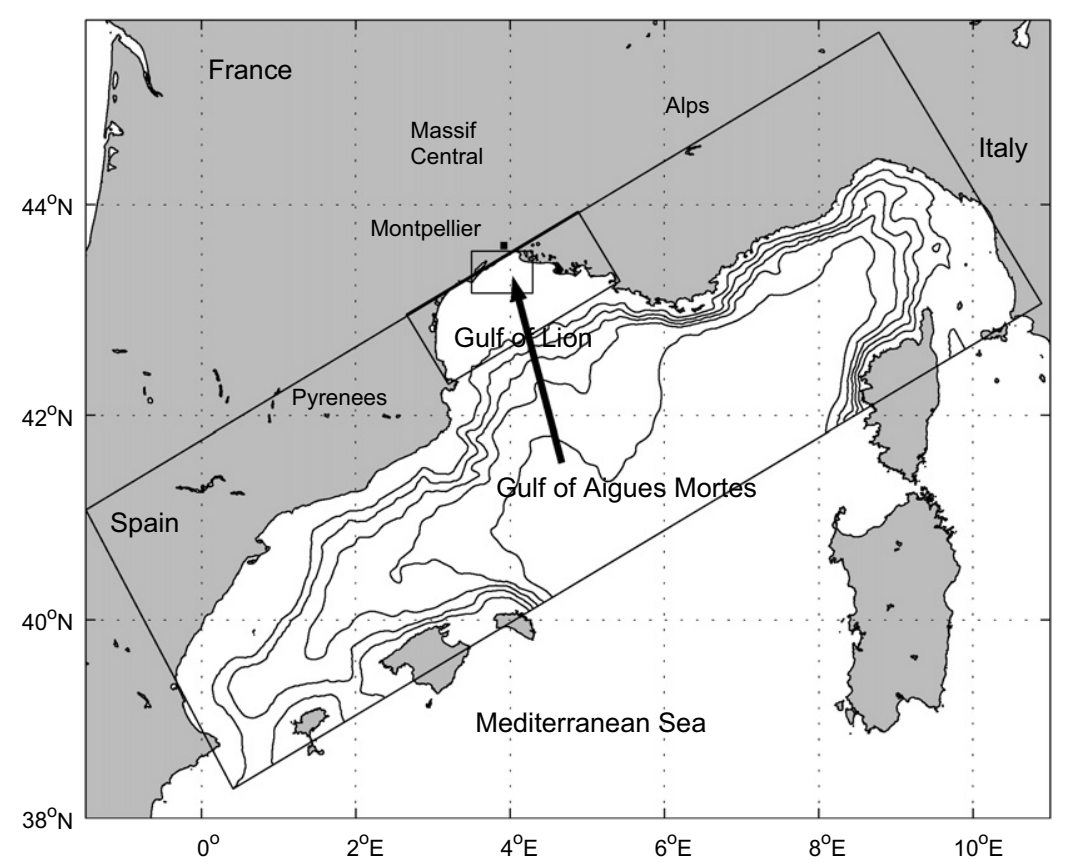

Fig. 1. Geographical situation of this study. Frames of the three nested modelling grids. Bathymetry of the largest modelling grid (isolines every $500 \mathrm{~m})$.

midshelf. It is the shelf zone which is further off the continental slope, and consequently the most further off the Mediterranean general circulation, i.e. the Northern Current (NC) (e.g. Millot, 1990). Nonetheless, this area is largely open offshore, and cannot be studied without taking into account the hydrodynamic and meteorological phenomena at large scale. Down to the $80 \mathrm{~m}$-isobath, the slope is low, on the order of $0.5 \%$. Offshore the $80 \mathrm{~m}$ isobath, the shelf is nearly flat up to the shelf break. Except for the harbour structures, the coast is sandy, and globally in erosion (e.g. Certain et al., 2005a and included literature). Urbanisation and tourism are intensively developed. The Montpellier urban area (Fig. 2) has a population of 400,000 habitants. The Sète harbour (Fig. 2) is the first French-Mediterranean fishing port with roughly $15,000 \mathrm{~T} / \mathrm{yr}$ of fish. Port Camargue (Fig. 2) is the first French-Mediterranean yachting harbour with 4800 pier places. Numerous resorts, Palavas-lesFlots and La Grande Motte (Fig. 2), for example, extended very rapidly in the 1960s, with the development of mass tourism. The stakes are thus crucial and scientific studies such as this one are expected by society and authorities. The quality of both GAM waters and shores are continuously threatened by water pollution and coastal erosion, which, in the long run, could cause irreversible alterations. For instance, the water of the gulf receives the discharges coming from the numerous urban settlements along and near the GAM. The sewage of the Montpellier area, after being treated and collected in a $10 \mathrm{~km}$ pipeline, is dumped in front of Palavas-les-Flots, in water $30 \mathrm{~m}$ deep (point $\mathrm{S}$ in Fig. 2). This sewage is able to modify the quality of the swimming water and to have uncontrolled impact on the marine ecosystem. For these reasons, the study of the hydrodynamic processes and the circulation of the GAM, presented here, is able to provide useful information to improve the water quality, and for coastal management.

As far as the NW Mediterranean Sea is concerned, the hydrodynamics at the GAM scale has been very poorly studied. Except a few studies, such as in the Gulf of Fos (Ulses et al., 2005) or along the Roussillon coast (Lamy et al., 1981), no study looked particularly at the hydrodynamics of the NW Mediterranean midshelf. Studies were indeed often centred on the whole GoL. For many years, the French national program of coastal environment (Raimbault and Durrieu de Madron, 2003) has focused on studies at regional scales. Experimental studies were carried out in the 1990s in the region, especially on the variation of the $\mathrm{NC}$ offshore of Marseilles (Conan and Millot, 1995), the sediment transport in canyons (Monaco et al., 


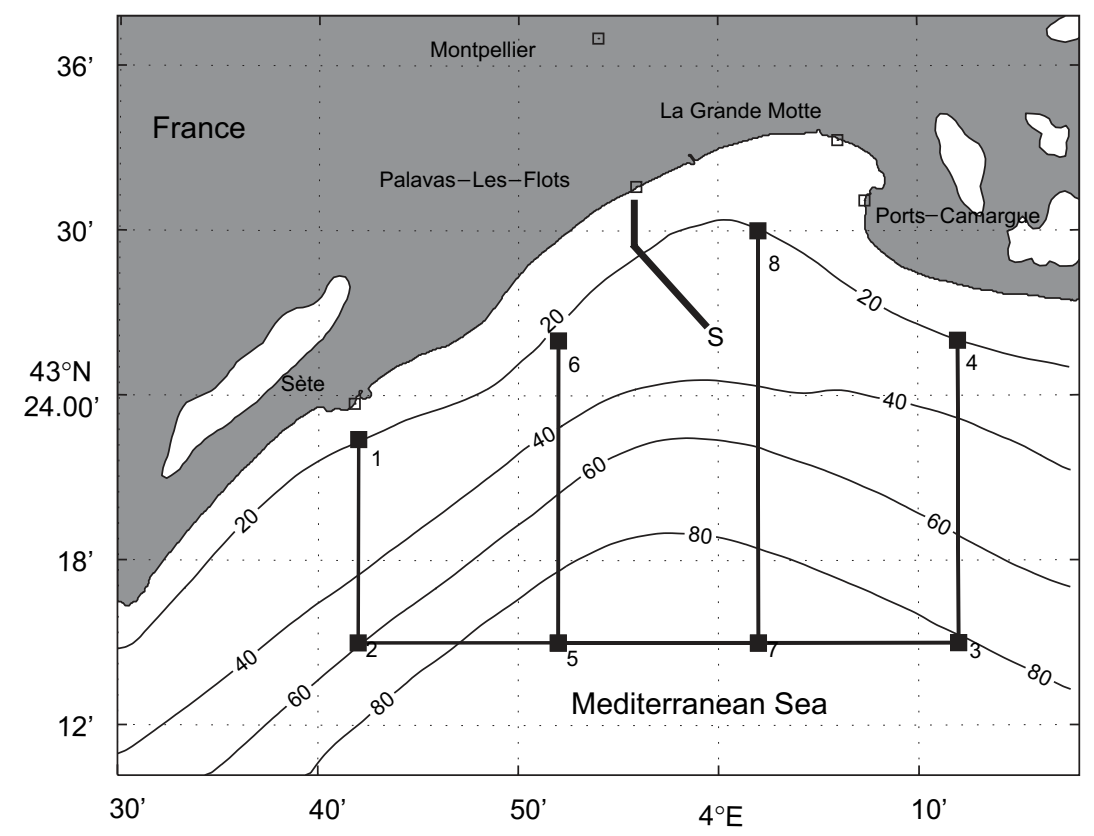

Fig. 2. Geographical situation of this study with the cities. Bathymetry (isolines, 20-80 m). HYGAM cruises main stations (squares 1-8) and tracks (straight lines). $\mathrm{S}$ is the Montpellier sewage dumping point.

1990) or at the shelf break (Durrieu de Madron et al., 1999; Lapouyade and Durrieu de Madron, 2001), the biogeochemical cycles in the gulf (Raimbault and Durrieu de Madron, 2003), and the Rhone River plume (Naudin et al., 2001; and included literature). More recently, the entire shelf circulation has been studied (Petrenko et al., 2005). Previous modelling works focusing on GoL dynamics have been done with primitive equations models based on Boussinesq and hydrostatic approximation (Delleville, 1997; Echevin et al., 2003; Estournel et al., 2003).

None of the cited studies are specific on the GAM. However, those with a larger-scale extension give insights into the GAM hydrodynamics. The 10 Sarhygol cruises, which took place on the whole GoL during 2000-2002 (Petrenko et al., 2005), have an ADCP transect at the south of the GAM between longitudes $3.9^{\circ} \mathrm{E}$ and $4.3^{\circ} \mathrm{E}$ at latitude $43.1^{\circ} \mathrm{N}$. These surveys show a large spatial and temporal variability of the currents.

Some studies clearly point out that the hydrodynamics at the GAM scale is mainly induced by winds. The winds, particularly the Tramontane blowing most often from north-north-west on the west side of GoL, and the Mistral, from the north on the east side of the GoL, have local effects, such as upwellings or downwellings (e.g. Lamy et al., 1981). Estournel et al. (2003) also show that these two winds (Tramontane and Mistral) induce large and temporary eddies on the GoL shelf. These coherent structures are able to control the GAM circulation.

Even if the $\mathrm{NC}$ flows most often along the continental slope $80 \mathrm{~km}$ south of the GAM, the NC can have cross-shore intrusions on the shelf (Gatti et al., 2005). These intrusions seem to be linked to the instabilities of the NC. In order to obtain realistic simulations of the hydrodynamics of the GoL shelf, including the GAM, the NC and its instabilities have to be carefully modelled.

In a similar manner, the GAM is far from the Rhone river outlet. Estournel et al. (1997), however, show that in the particular southeast winds conditions the river plume can be pushed towards the GAM. This is, however, not the case in general. The GAM is excluded by the discharges of the closest main rivers: the "petit Rhone" river at east $\left(4^{\circ} \mathrm{E} 24^{\prime}\right)$, and the "Hérault" at west $\left(3^{\circ} \mathrm{E} 26\right)$, which are both outside the GAM.

The GAM is then not affected by relevant brackish that could increase the buoyancy. It is also the more northern zone of the GoL. Although it has never been directly observed, the GAM could be a good location for dense water formations. Observed in other locations of the GoL shelf, these dense water formations generate the Western Mediterranean Intermediate Water's (WIW's) (e.g. 
Dufau-Julliand et al., 2004). The spreading of these dense waters can transport large amounts of water and sediment, reshape submarine canyon floors and affect the deep-sea environment (Canal et al., 2006).

Although marginally describing the GAM, the past investigations point the importance of this area, while they leave numerous questions still not answered. Thus, the aim of this study is to continue these previous works, with a specific focus on the GAM.

First, using the CTD data and the velocity measurements collected during three short HYGAM (HYdrodynamics in the Gulf of AiguesMortes) cruises, we describe the hydrographic characteristics and the circulation of the gulf. In addition, since the cruises occurred during different weather conditions, we also illustrate the various circulation scenarios in response to different wind forcing, highlighting the dominant role that the winds have in driving the circulation. Second, using the dataset collected during the HYGAM cruises, we are able to validate the 3D Symphonie model (e.g. Estournel et al., 2003), and we can use the model to identify the dominant processes that generate the observed currents. The model output data are also used to reproduce a numerical experiment in which we study the dispersion of a fictive contaminant dumped at point S (Fig. 2).

The paper is organised as follows. In Sections 2 and 3, we describe the methods and the results of this study. In both sections, we present first what concerns the in situ observations and second what is related to the model output. In Section 4, some applications are discussed and we present a concrete one about contaminant dispersion.

\section{Methods}

\subsection{The HYGAM cruises}

Three short cruises (HYGAM: HYdrodynamics in the Gulf of Aigues-Mortes) were taken in March-April 2005 to survey hydrodynamics features across the GAM. They were scheduled approximately every 15 days to sample the gulf circulation under different weather conditions. In addition, the measurements collected during the cruises were used to validate the numerical model Symphonie. The cruises took place during March 6-7, 20-21 and April 5-6, 2005, leaving from and returning to Sète, France (Fig. 2). In order to get a quasi-synoptic view of the circulation, the RV
Tethys II covered the entire gulf as quickly as possible with a maximum speed of eight knots. Any vessel velocity higher than the one used would have compromised the quality of the data. Continuous measurements were made with a RD Instruments hull-mounted ADCP, and a Seabird thermosalinograph connected to a pumping system and a Batos meteorological station. CTD measurements were also regularly performed along the cruise track.

The ADCP is a broadband VMBB of $150 \mathrm{kHz}$. The configuration used during all cruises is identical: 60 cells, $4 \mathrm{~m}$ depth bins, an ensemble average of $1 \mathrm{~min}$, and bottom tracking when possible. Precision on the ADCP data is better than $0.02 \mathrm{~m} \mathrm{~s}^{-1}$. Thermosalinograph and CTD data were analysed with the Seasoft software (http://www.seabird. com/software/Seasoft.htm).

Wind was measured every $15 \mathrm{~s}$ by the on board meteorological station Batos. These data were averaged every $30 \mathrm{~min}$. Moreover, the coastal weather data at the stations of Sète, La GrandeMotte and Port Camargue (see locations in Fig. 2) were kindly provided by Météo-France. For both the analysis of in situ observations and modelling outputs, it is necessary to know the meteorological conditions before and during the cruise throughout the entire northwestern Mediterranean, and not be limited to the conditions along the cruise track. The Aladin weather-forecast model was used to provide the necessary additional meteorological information. Winds modelled by Aladin are averaged over a 3 -h period, on a $0.1^{\circ}-0.1^{\circ}$ grid throughout the gulf.

\subsection{The circulation model}

In this paper, modelling is carried out with the Symphonie model, the description of which can be found in Estournel et al. (2005), Petrenko et al. (2005), Ulses et al. (2005), together with recent examples of applications. This model belongs to the family of models based on Boussinesq and hydrostatics approximations, using a sigma coordinate formalism and having a free-surface elevation, as the well-known POM (Blumberg and Mellor, 1987) and ROMS (Shchepetkin and McWilliams, 2005) models. The three components of the current, surface elevation, temperature and salinity are computed on a C grid, using classical finite difference methods. The turbulence closure is achieved through a prognostic equation for the turbulent kinetic energy and a diagnostic equation for the mixing and dissipation length scales (Gaspar 
et al., 1990). A leap frog scheme is used for the time stepping. Calculus costs are limited thanks to a time splitting technique that permits one to compute the vertical shear of the current and its depth-averaged component separately with appropriate time steps.

The external forcing is of three types: river discharges, atmospheric fluxes and open boundary conditions. The atmospheric forcing is provided by the $3 \mathrm{~h}$ averaged outputs of the weather-forecast model Aladin. Open boundary conditions have a double purpose. They are, first of all, required to force the inner solution with external fields under incoming conditions. Secondly, they should allow waves to radiate out or water masses to leave the modelling domain under outgoing conditions, without any spurious reflections. Sea surface elevation and barotropic currents are given by the Flather radiative condition (Flather, 1976) using the numerical scheme recommended by Marsaleix et al. (2006). Baroclinic velocities are given by a zero gradient condition in the direction normal to the boundary. Temperature and salinity boundary conditions use the same equations as for the inner solution, but with an upstream advection scheme in order to advect external fields into the numerical area under inflow conditions. A boundary-nudging layer enforces external forcing. In this layer, a restoring term $-\left(\left(\phi_{\mathrm{F}}-\phi\right) / \tau_{\mathrm{R}}(x, y)\right)$ is added to the right-hand side of the model equations, where $\phi$ stands for tracers or velocities variables and subscript $F$ refers to forcing terms. The restoring time scale $\tau_{\mathrm{R}}(x, y)$ is such that this additional term progressively vanishes with the distance to the open boundaries.

In this paper, the model is applied to nested domains. The largest domain extends over the whole Northwestern Mediterranean sea (see Fig. 1) with a $3 \mathrm{~km}$ horizontal grid mesh and 41 vertical levels. This largest domain indeed allows the simulation of the general circulation, mainly the $\mathrm{NC}$ and its instabilities, and so its intrusions (see "Introduction"). The simulation over this domain lasts from 1 January to 10 April 2005. It was obtained in the framework of the MFSTEP European project (http://www.bo.ingv.it/mfstep/), an operational oceanographic system delivering, every week, forecasts and hindcasts of the Mediterranean Sea. MFSTEP is based on a global Mediterranean Sea model assimilating sea level altimeter data, surface temperature and XBT temperature profiles. This project also involves several higher-resolution embedded models down- scaling the global solution to regional or coastal scales (Zodiatis et al., 2003; Auclair et al., 2006). Our model is actually directly derived from the MFSTEP regional model of the Northwestern Mediterranean Sea. This regional model has been specially replayed for the purpose of our study. We indeed performed a 4 month continuous run forced with meteorological and MFSTEP global re-analysis. This regional simulation provided high-frequency $(3 \mathrm{~h})$ outputs in order to force our coastal high-resolution sub-models.

Instead of nesting the smallest domain of interest for our GAM study directly in this biggest domain, an intermediate domain, at the scale of the GoL shelf (see Fig. 1), is implemented with a $1 \mathrm{~km}$ horizontal grid mesh and 26 vertical levels. This domain permits one to represent well the interactions between the general circulation (the NC), the shelf circulation mainly induced by the winds, and fresh waters mainly discharged from the Rhone river.

Finally, the smallest modelling domain extends on the northern part of the inner shelf of the GoL, i.e. the GAM (see Fig. 1) with a $500 \mathrm{~m}$ horizontal grid mesh and 10 vertical levels. The simulation on this domain, lasting from 1 March to 10 April 2005, permits a comparison between model results and in situ data during the three HYGAM cruises.

\section{Results and discussions}

In the following subsections, we will discuss both in situ data and the corresponding model inputs or outputs, in situ data will be compared with the model data. The degree of agreement will indicate to what extent model results can help in understanding the observations.

\subsection{Winds}

The shelf circulation of the GoL is dominated by the effects of the wind. It is locally highly variable and its curl is known to induce specific mesoscale currents (Estournel et al., 2003) encroaching on the GAM area. Three types of data are available: the coastal weather stations data, the onboard meteorological Batos station data, and the Aladin meteorological model data. The comparison of the wind measurements obtained by these three data types are shown in Fig. 3. The three ensembles of measurements present an overall good agreement that justify the use of the Aladin model to 

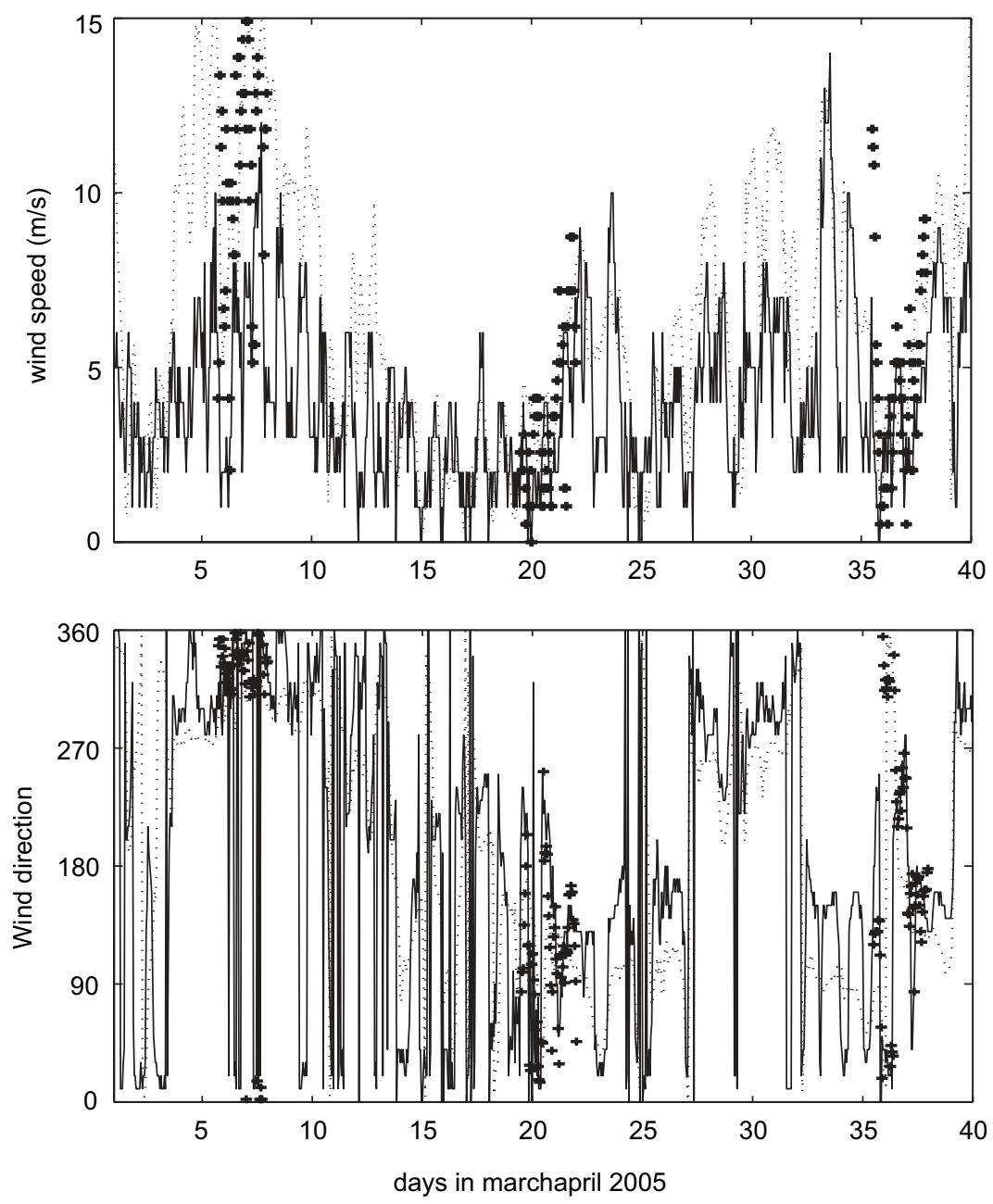

Fig. 3. Wind speed and direction measured at La Grande Motte (solid line), modelled by Aladin at the same location (dotted line) and measured on the RV during the cruises $(+)$.

realistically force the ocean circulation model Symphonie. After a period of relative atmospheric calm at the beginning of March, the period corresponding to the first HYGAM cruise (March $6-7)$ is characterized by strong winds which fluctuate between the north-north-west and north at La Grande Motte. These two directions correspond to very frequent winds in this region, called Tramontane and Mistral, respectively. The Batos station data confirm the occurrence of these strong winds (between 5 and $15 \mathrm{~m} \mathrm{~s}^{-1}$ ). The Aladin model results are also in good agreement with the various types of data (for example, see Fig. 3 for the station of La Grande Motte).

The local orography plays a key role on wind fields: Tramontane blows between the Pyrenees and the Massif Central (Fig. 1); Mistral blows in the Rhone valley between the Massif Central and the Alps (Fig. 1). These two winds are then relatively well channelled, the Tramontane blowing most often from north-north-west on the west side of the GoL, and the Mistral, from the north on the east side of the GoL. This typical situation occurs during the first HYGAM cruise. The GAM is at the convergence of these two winds. Fig. 4 shows how the east part of the gulf, on March 6, is under a Mistral of intensity above $10 \mathrm{~m} \mathrm{~s}^{-1}$, how the west part is under a Tramontane of the same intensity, and how the winds are nearly absent in the central part of the gulf.

After the first cruise, the winds' intensity weakens until March 20 (Fig. 3), the beginning of the second 


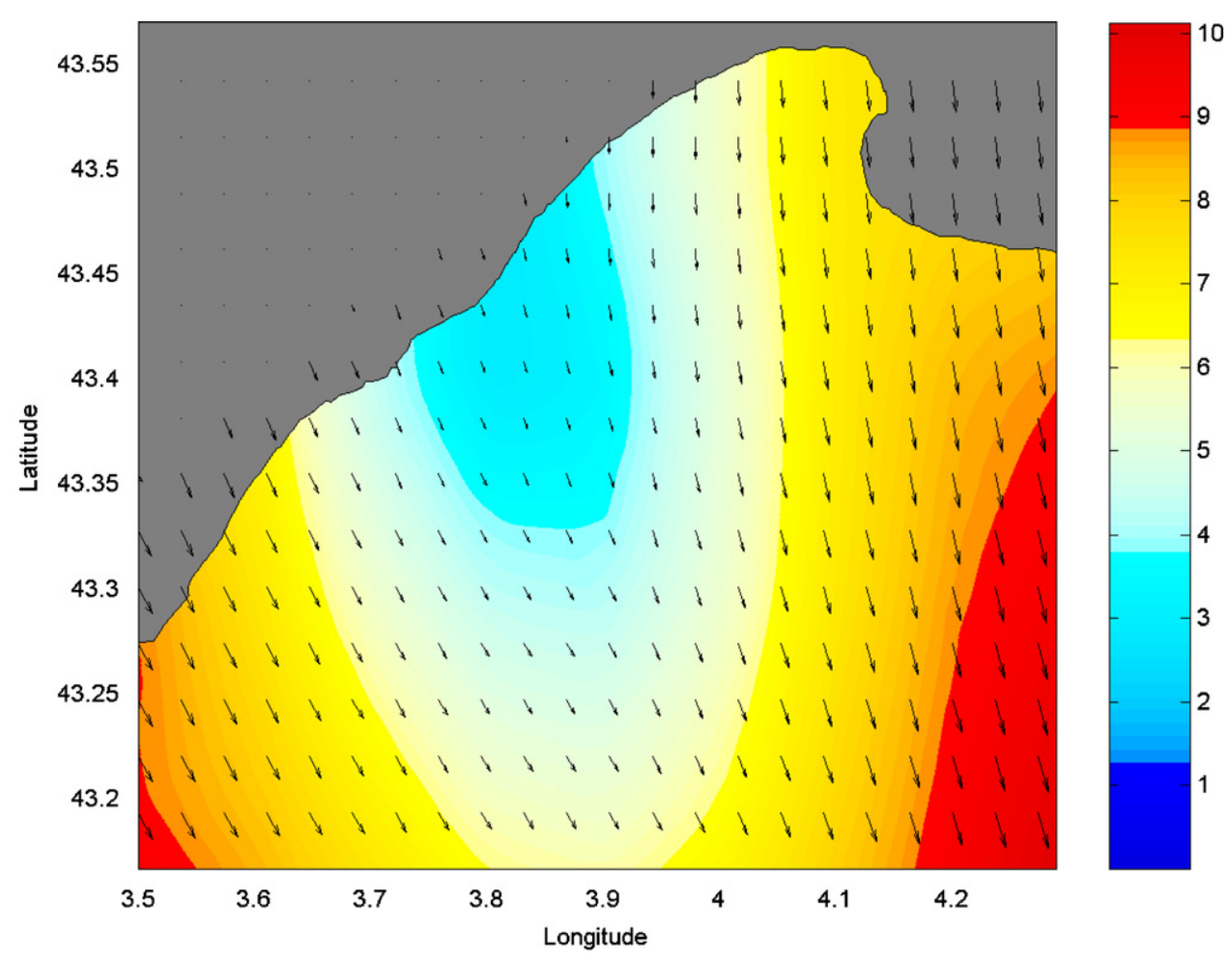

Fig. 4. Wind (arrows and colours; $\mathrm{m} \mathrm{s}^{-1}$ ) modelled by Aladin at 12:00 h on 6 March.

HYGAM cruise for which the sea state was nearly calm (slack sea at the beginning of the cruise). During this second cruise, the good agreement between each type of data can be noticed (Fig. 3). It shows a drift from south to east winds, and a progressive increase in the wind intensity up to $10 \mathrm{~m} \mathrm{~s}^{-1}$ at the end of the cruise (March 21).

The end of March is characterized by an important variation in weather conditions, with alternations of calm periods (March 25), of east winds (March 26), of Tramontane (March 28), and of Mistral (March 31), with relatively strong intensities. At the beginning of April, the winds are from east and south-east, with strong intensities as high as $14 \mathrm{~m} \mathrm{~s}^{-1}$ measured and modelled on 2 April. On 5 April, at the beginning of the third HYGAM cruise, these southeasterly and easterly winds weaken and then strengthen at the end of the cruise, on 6 April.

The weather conditions that occurred during the three HYGAM cruises were typical of this region: (1) north and north-west winds; (2) fine weather; (3) south and south-east winds. The measured data should then permit one to understand the oceanic circulation during such conditions.

\subsection{Hydrology}

Two types of hydrological data are available: the surface data acquired continuously by the thermosalinograph and the CTD data. Some representative data will be presented in the next paragraphs.

The salinity is nearly constant during the whole period and spatially uniform in the studied region, except for some small brackish zones of small coastal rivers plumes. On the contrary, the temperature fluctuates strongly during the whole studied period, depending on the time and the location. The CTD samplings (76 done during the three HYGAM cruises) clearly show this variability. Various temperature profiles measured at two particular stations during the three HYGAM cruises are shown in Fig. 5. The first ones are from the outer shelf station 7 at $43^{\circ} \mathrm{N} 15^{\prime}-4^{\circ} \mathrm{E} 02^{\prime}$. The second ones are from the station 8 near the coast at $43^{\circ} \mathrm{N} 30^{\prime}-4^{\circ} \mathrm{E} 02^{\prime}$ (see positions on Fig. 2).

Because of a particularly cold winter during 2004-2005, the coastal waters are extremely cold at the beginning of March $\left(9.7^{\circ} \mathrm{C}\right.$ at station 8 on 6 March). The water column is vertically homogeneous. Differently, the offshore water is one degree 


\section{a}

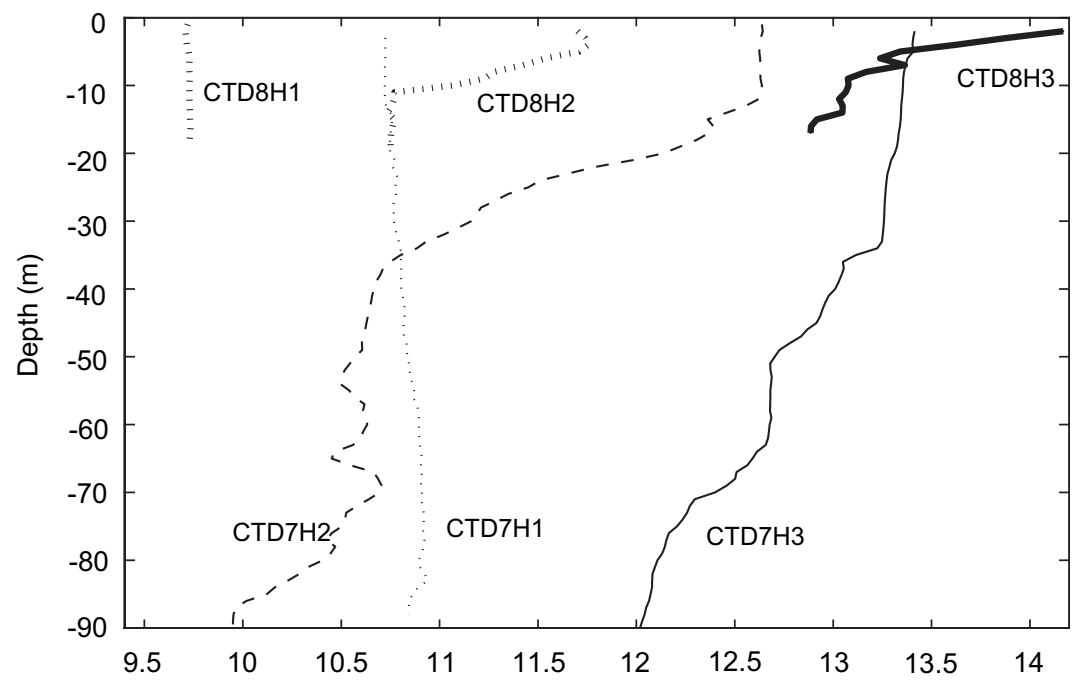

b

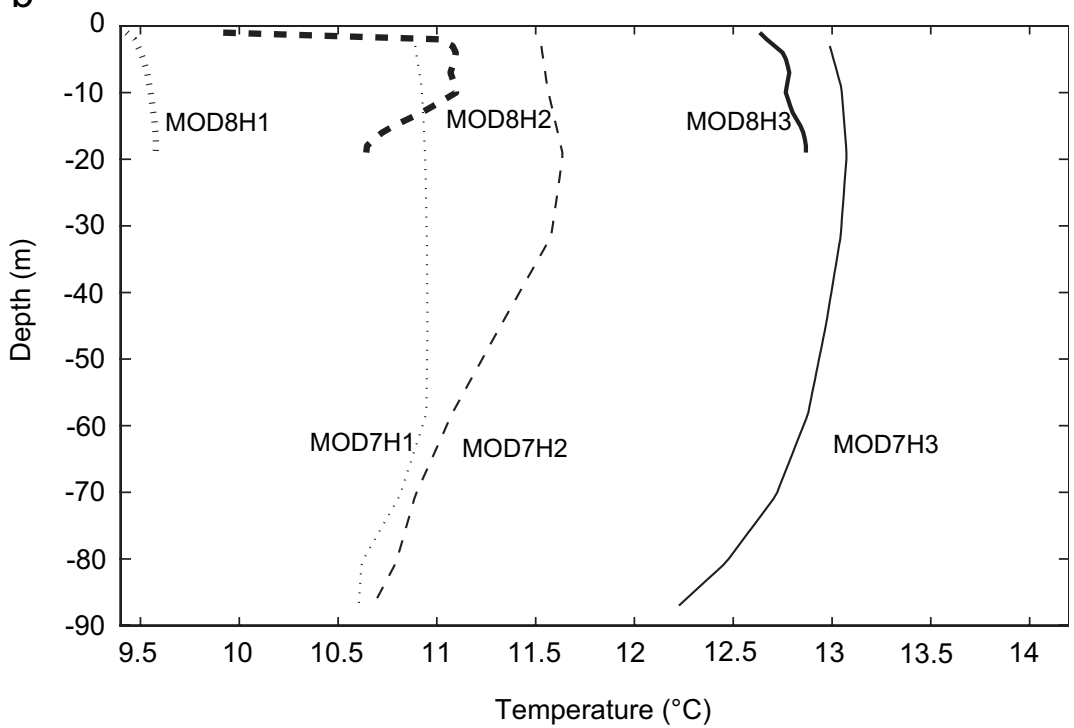

Fig. 5. Temperature profiles: (a) measured at station 8 during HYGAM 1, at 18:10 h on 6 March (CTD8H1), during HYGAM 2, at 06:33 h on 20 March (CTD8H2), during HYGAM3, at 20:11 h on 5 April (CTD8H3), measured at station 7 during HYGAM 1, at 11:04 h on 6 March (CTD7H1), during HYGAM 2, at 00:16 h on 21 March (CTD7H2), during HYGAM3, at 08:50 h on 5 April (CTD7H3), (b) simulated at the same places and times (MOD8H1, MOD8H2, MOD8H3, MOD7H1, MOD7H2, MOD7H3).

warmer, $10.7^{\circ} \mathrm{C}$ at station 7 on 6 March. The comparison between the observations and the model output (Figs. 5 and 6) highlights the good agreement between the two data sets. Vertically, the discrepancy between the observed and modelled temperature profile $\mathrm{H} 1$ is less than $0.2^{\circ} \mathrm{C}$ (Fig. 5). Horizontally, we remark that the model is able to reproduce the cold coastal water event observed on 6 March (Fig. 6). At the surface, warmer waters are brought up due to a northward flux creating an important temperature gradient $\left(>2{ }^{\circ} \mathrm{C}\right)$ between offshore and coastal waters (Fig. 6a). The data of the thermosalinograph (Fig. 6b) confirm this strong gradient. The presence of cold water masses is undoubtedly related to the formation of the western Mediterranean intermediate water's (WIW's) discussed in Dufau-Julliand et al. (2004). The results of Fig. 6 point out the positive correlation between the 
a

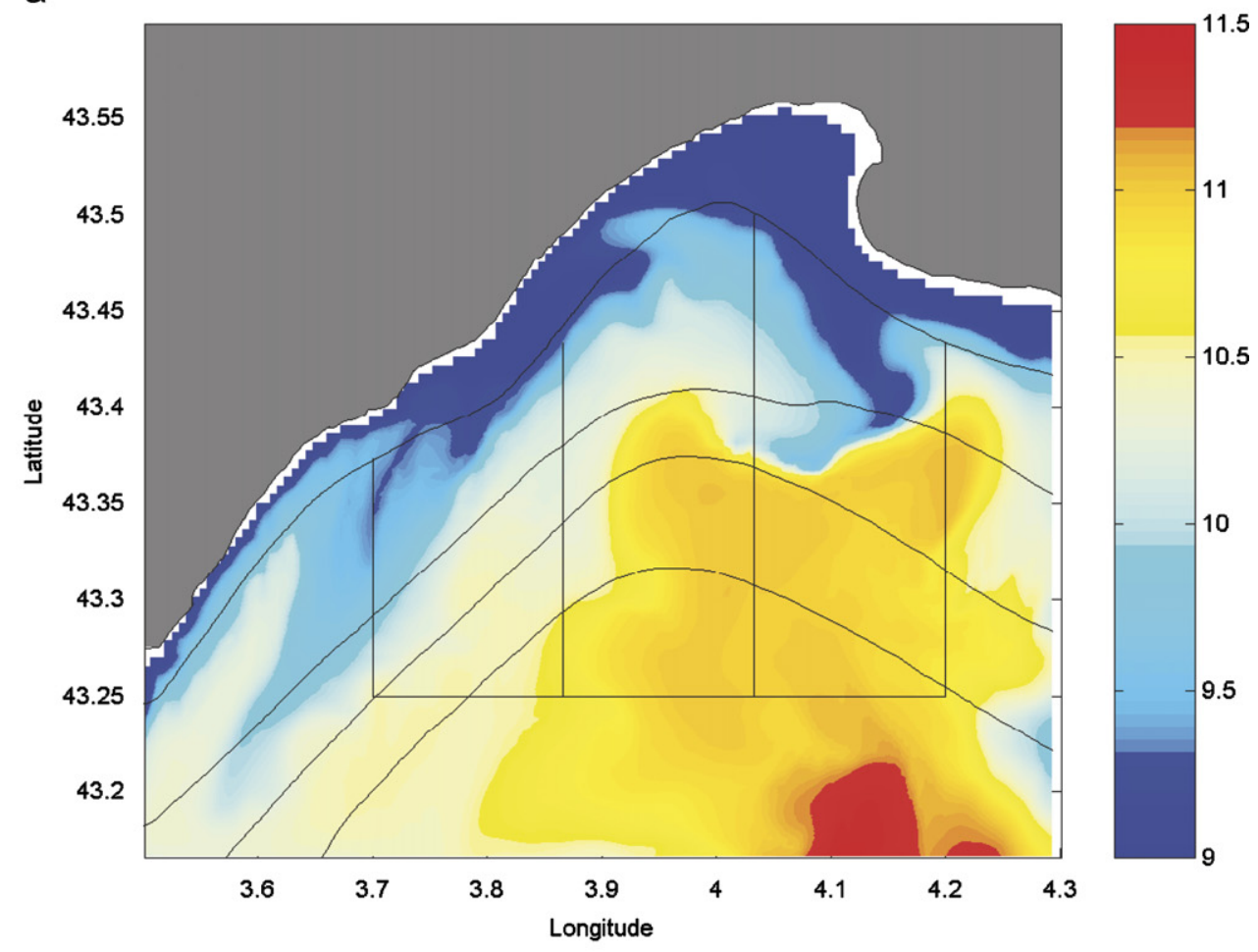

b

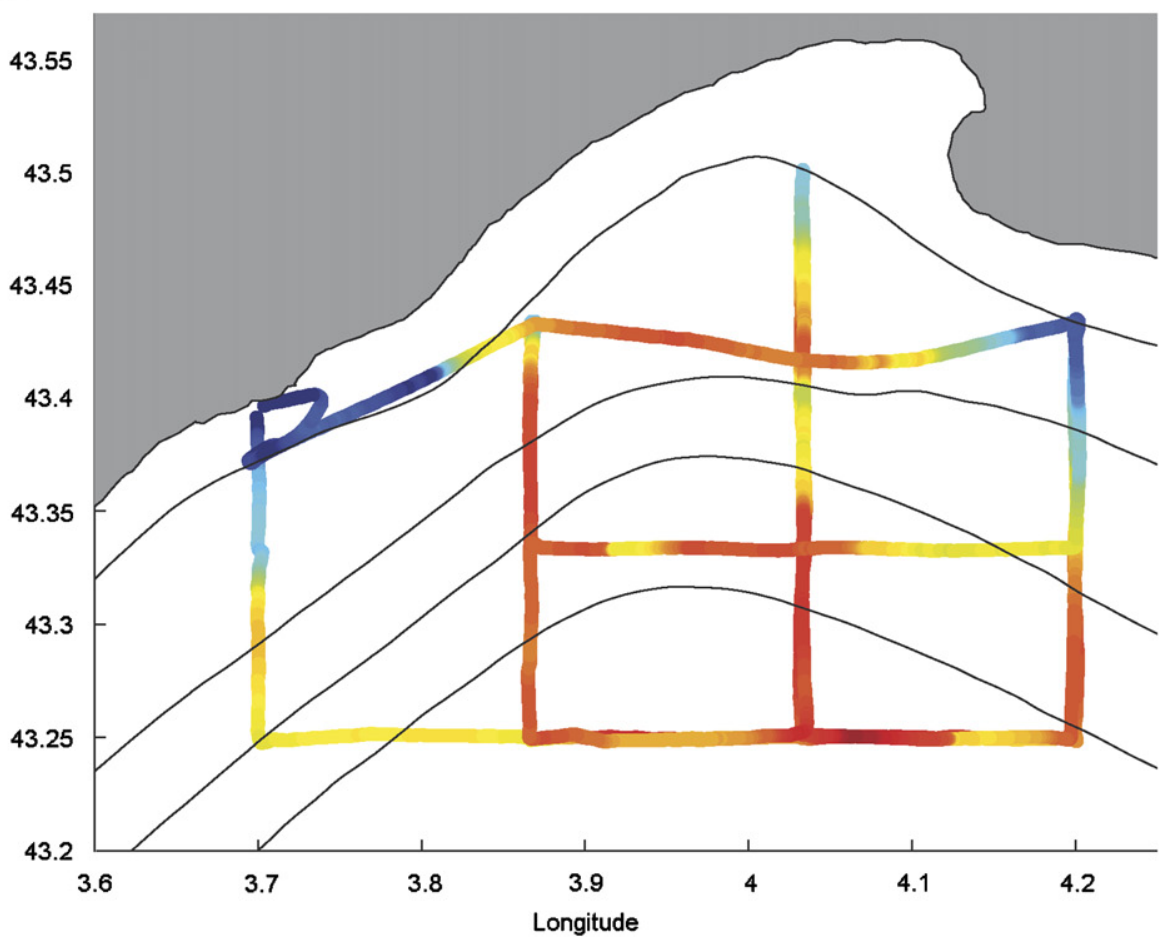

Fig. 6. Surface temperature $\left({ }^{\circ} \mathrm{C}\right)$ : (a) modelled by Symphonie at 12:00 h on $6 \mathrm{March}$, (b) measured by the Tethys' thermosalinograph on 6 March (same colour scale than (a)), 
cold northerly winds and the presence of dense water. This also suggests that the GAM, being away from big rivers plume and, therefore, not affected by the relevant brackishness that could increase the buoyancy, could be a well-disposed location for the dense-water formation. However, this topic goes beyond the main goal of this paper, hence we reserve a detailed discussion to a future dedicated project.

On 20 March, coastal waters have warmed up $\left(11.3{ }^{\circ} \mathrm{C}\right.$ at $10 \mathrm{~m}$ at station 8$)$. The temperature gradient between offshore and coastal waters is now less pronounced $\left(12.6^{\circ} \mathrm{C}\right.$ at $10 \mathrm{~m}$ at station 7$)$. The fine weather period enhances this warming, and the water column stratification has begun $\left(10.0^{\circ} \mathrm{C}\right.$ at $90 \mathrm{~m}$ at station 7). The model follows this warmingup tendency. It displays the appropriate range of values, but does not reproduce the vertical gradient. The warmed layer is slightly too thick in the model. This might be caused by an inappropriate parametrisation of the attenuation of surface irradiance with depth in our model. This parametrisation is based on an exponential decay law, $\mathrm{e}^{z / d}$, depending on a vertical scale parameter, $d=22 \mathrm{~m}$, which roughly corresponds to the clear water case (case one) of the Jerlov water type classification (Apel, 1987). Actually one can expect nearshore waters to be turbid because of biogeochemical activities or suspended matter brought by rivers or bottom turbulence, and consequently, the vertical-scale parameter used in our parametrisation will be much smaller. An adjusted value of this parameter might lead to a better representation of the warmed-layer thickness.

The warming continues until 5th April, when, for the first time, the coastal waters have the same temperature than the offshore waters $\left(13.5-14.1^{\circ} \mathrm{C}\right.$ at the surface on Fig. 5). The model still slightly underestimates this warming, especially near the coasts, but shows a horizontal homogenisation trend (data not shown). The data from the thermosalinograph (not shown) confirm the warming of the coastal waters and display relatively cold offshore waters, near $13.0^{\circ} \mathrm{C}$ (principally south-west of the studied region). The $\mathrm{CT} 7 \mathrm{H} 3$ profile (Fig. 5) shows that the water column is relatively less stratified than 16 days before $\left(0.9^{\circ} \mathrm{C}\right.$ instead of $2.6{ }^{\circ} \mathrm{C}$ between surface and bottom). This reduced stratification is a consequence of the vertical mixing favoured by the weather conditions. The model, which tends to be more vertically homogeneous, is then closer to reality.

\subsection{Circulation}

The ADCP data measured at $16 \mathrm{~m}$ depth along the first track of the HYGAM 1 cruise (between 8:00 h on March 6 and 6:00h on March 7) are represented in Fig. 7a. Results for data available at every $4 \mathrm{~m}$ depth (figures not included) exhibit an important vertical homogeneity of the circulation. This vertical homogeneity is confirmed by representing vertically the data measured along transect 7-8 (south-north, longitude $4^{\circ} 02^{\prime} \mathrm{E}$ ) in Figs. $8 \mathrm{a}$ and c. It is worth noting that the ADCP data are valid when located between $12 \mathrm{~m}$ above the bottom (due to acoustical reflexion and interferences) and $16 \mathrm{~m}$ under the sea surface (due to the hull and acoustical blanking). Thus, the ADCP gives generally valid data offshore of the $30 \mathrm{~m}$ bathymetry line, while at a depth shallower than that it is necessary to complete the ADCP data with model output.

The corresponding model results (shown in Fig. $7 \mathrm{~b}$ at 12:00 $\mathrm{h}$ on March 6 at $16 \mathrm{~m}$ depth) are very close to the in situ data. The model results are represented in Figs. $8 \mathrm{~b}$ and $\mathrm{d}$ along the same transect than the data at 12:00 $\mathrm{h}$ on 6 March. These figures confirm that the velocity fields are nearly homogeneous on the whole water column, and not only at the measured depths. The data measured at $16 \mathrm{~m}$ depth (Fig. 7a) are then representative of the surface currents. This vertical homogeneity in velocity corresponds to the temperature vertical homogeneity (see \$3.2.), characteristic of the winter period. In a general case, and particularly in summer, we will have to be very cautious when interpreting the currents measured at $16 \mathrm{~m}$ depth as representative of the surface currents.

Near the bottom, below $40-50 \mathrm{~m}$ depth, the model however shows that the currents tend to decrease, and even reverse. Even if there is no in situ data to confirm this bottom drift towards deep sea, the bottom seaward flux is consistent with the transport offshore of the cold and denser waters participating to the export of the WIW outside the shelf.

Except near the interfaces where real observations are missing, the near-perfect consistency between the observed and the simulated data allows a detailed analysis. In Fig. 7a, the data of the three western transects show currents toward the west and the south-west-west offshore of the $40 \mathrm{~m}$-isobath. These currents can locally reach $0.20 \mathrm{~m} \mathrm{~s}^{-1}$. The model reproduces well this flux present on the western part of the GAM with weaker intensity 

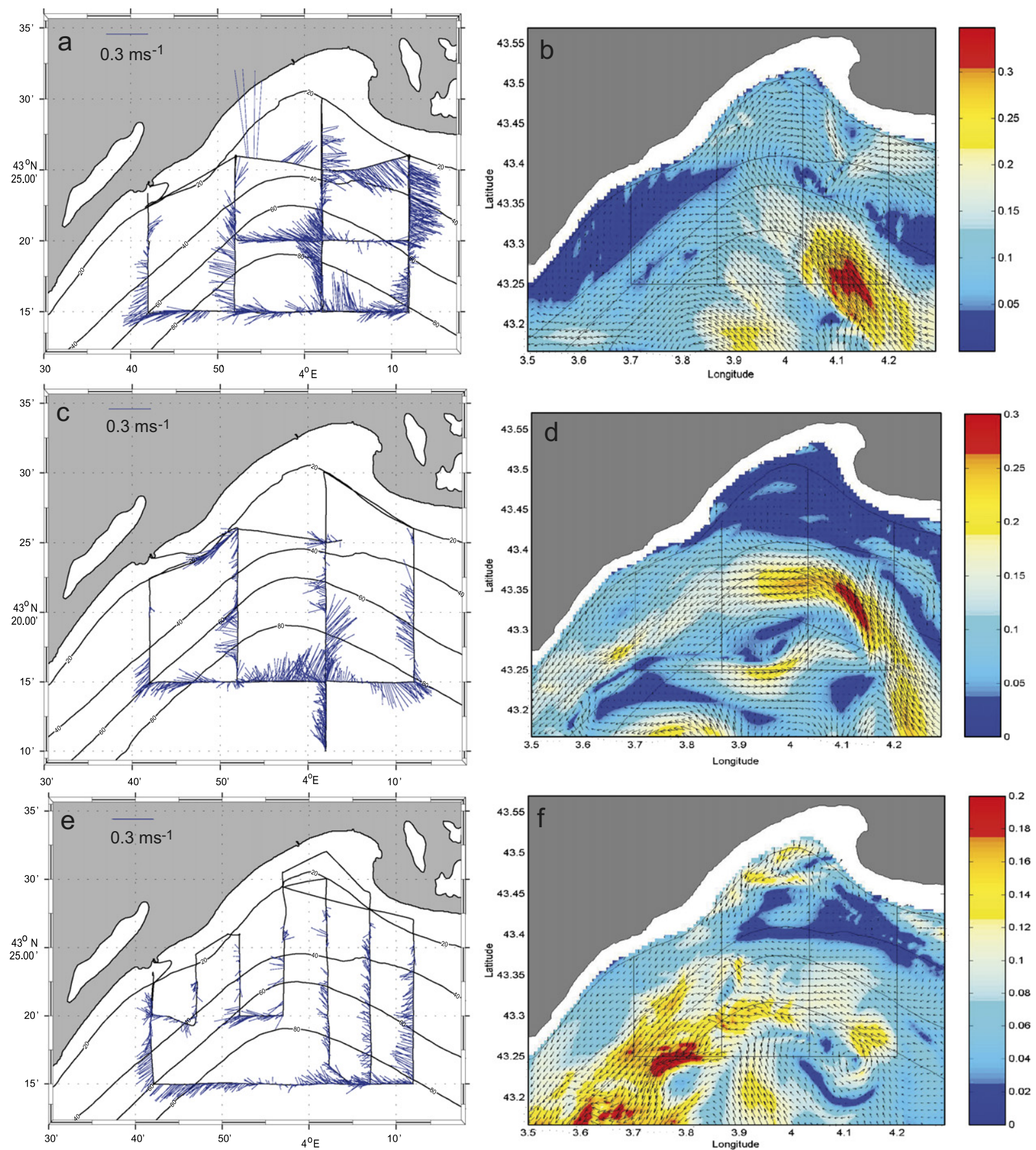

Fig. 7. (a) Currents measured at $16 \mathrm{~m}$ depth along the cruise track between 08:00 h on 6 March and 06:00 h on $7 \mathrm{March}$. (b) Currents (colours and arrows, $\mathrm{m} \mathrm{s}^{-1}$ ) modelled by Symphonie at 12:00 h on 6 March at $16 \mathrm{~m}$ depth. (c) Currents measured at $12 \mathrm{~m}$ depth along the cruise track between 17:00 h on 20 March and 15:00 h on 21 March. (d) Currents (colours and arrows, $\mathrm{m} \mathrm{s}^{-1}$ ) modelled by Symphonie at 06:00 h on 21 March at $12 \mathrm{~m}$ depth. (e) Currents measured at $16 \mathrm{~m}$ depth along the cruise track between 06:00 h on $5 \mathrm{April}$ and 05:00 h on 6 April. (f) Currents (colours and arrows, $\mathrm{m} \mathrm{s}^{-1}$ ) modelled by Symphonie at 12:00 h on 5 April at $16 \mathrm{~m}$ depth.

$\left(0.12 \mathrm{~m} \mathrm{~s}^{-1}\right)$. Closer to the coast (onshore of the $40 \mathrm{~m}$-isobath), sparse data exhibit currents in the opposite direction with very weak intensity. The model also gives very low values of velocities nearshore (onshore of the $40 \mathrm{~m}$-isobath), where we get closer to the atmospheric calm zone (see Fig. 4). 
a

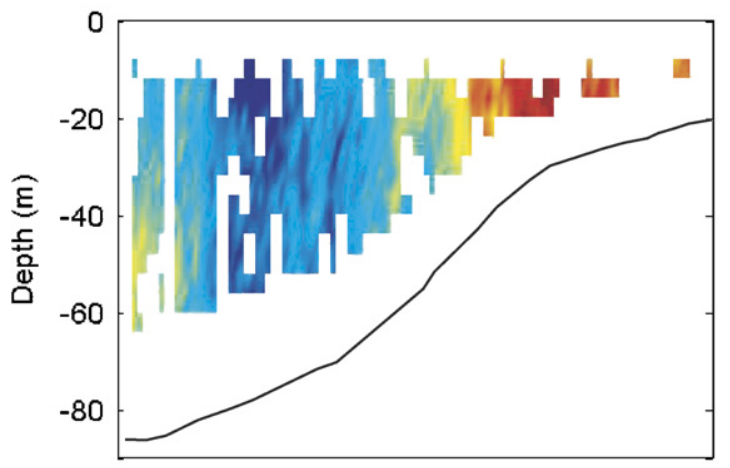

C

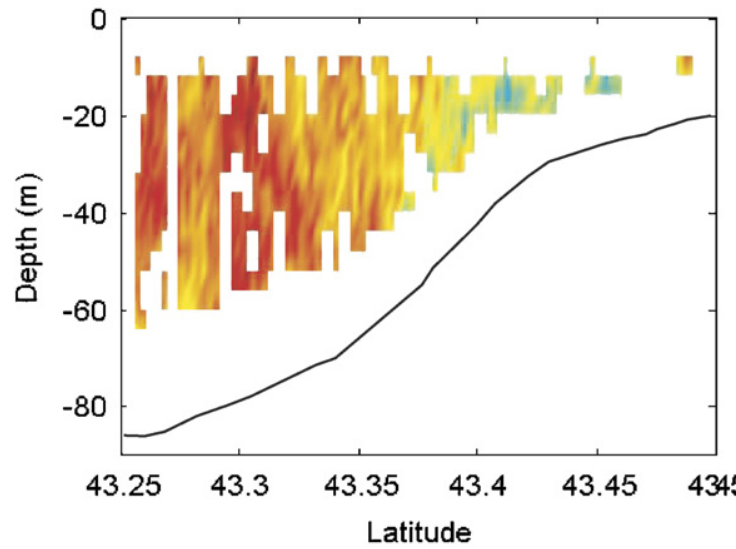

b

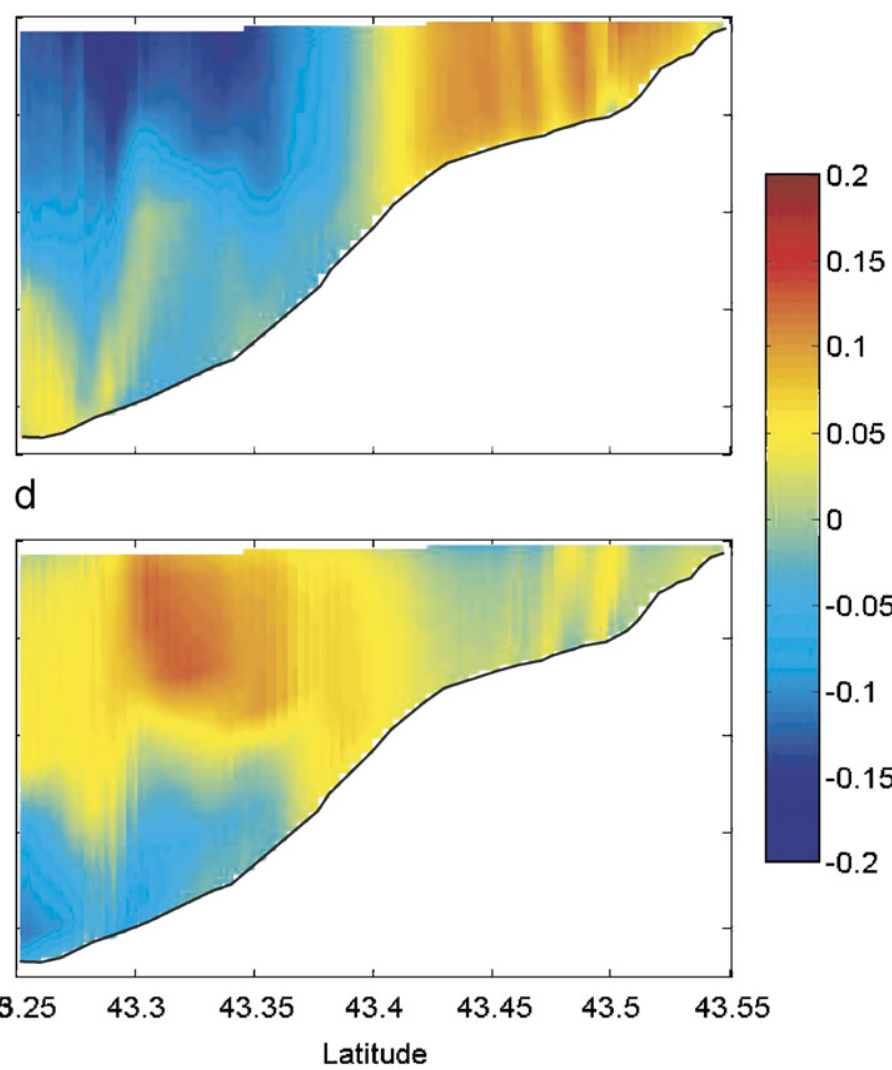

Fig. 8. Vertical sections (depth vs. latitude) of the currents (colours, $\mathrm{m} \mathrm{s}^{-1}$ ) on 6 March along transect $8-7$ (longitude $4^{\circ} 02^{\prime} \mathrm{E}$ ): (a) observed eastward component, (b) simulated eastward component, (c) observed northward component, (d) simulated northward component

As the Tramontane seems to control the circulation in the western part of the GAM, the Mistral seems to control the circulation of the eastern part of the GAM. The data of the three eastern transects show currents toward the east and the southeast-east between the 20 and $60 \mathrm{~m}$ isobaths. The data show these currents can locally reach $0.30 \mathrm{~m} \mathrm{~s}^{-1}$. The model reproduces well this waters export of GAM toward the east with a mean flow on the order of $0.20 \mathrm{~m} \mathrm{~s}^{-1}$ focused between the 20 and $60 \mathrm{~m}$ isobaths.

In the central part of the GAM, the strong correlation between wind and currents is less evident. Whereas the atmospheric flux is mainly southward, the oceanic flux seems northward. More precisely, the more-offshore transect data show currents globally westward, and even locally northward (longitude $4^{\circ} 05^{\prime} \mathrm{E}$, with an intensity up to $0.30 \mathrm{~m} \mathrm{~s}^{-1}$ ). The eastern transect exhibits a break at $60 \mathrm{~m}$-isobath between the nearshore waters going eastward and the offshore ones going westward.
The transect 7-8 (Fig. 8) also displays a change in direction. The southern data of this transect (up to $43.30^{\circ} \mathrm{N}$ ) show a northward current at $0.16 \mathrm{~m} \mathrm{~s}^{-1}$. Figs. $8 \mathrm{a}$ and c show between $43.30^{\circ} \mathrm{N}$ and $43.35^{\circ} \mathrm{N}$ a north-westward current that can reach $0.28 \mathrm{~m} \mathrm{~s}^{-1}$. Weaker currents are measured between $43.35^{\circ} \mathrm{N}$ and $43.40^{\circ} \mathrm{N}$. Nearshore, north of the latitude $43.40^{\circ} \mathrm{N}$, the current is reversed, going eastward at $0.20 \mathrm{~m} \mathrm{~s}^{-1}$. The model gives results close to the observations with a north-westward current south of latitude $43.40^{\circ} \mathrm{N}$, and an eastward current north of this latitude (Figs. 8b and d).

With this typical meteorological situation of Tramontane (north-northwest wind) and Mistral (north wind), channelled west and east of the GAM, respectively, an important oceanic circulation occurs northward and north-westward in the central part of the GAM. This circulation splits, turning toward west and southwest-west in the western part of the GAM and turning eastward in the eastern part of the GAM. 
During the Sarhygol 3 cruise (13-15 June, 2000), concerning the whole GoL's shelf, with the same meteorological conditions (channelled Tramontane and Mistral), Petrenko et al. (2005) observed the same northward flux between longitudes $3.9^{\circ} \mathrm{E}$ and $4.3^{\circ} \mathrm{E}$ at latitude $43.1^{\circ} \mathrm{N}$. They interpreted this flux to be an intrusion of the NC. Estournel et al. (2003), using modelling output, suggested that such intrusions in the middle of the shelf are due to the water pumping created by a cyclonic circulation on the western side of the GoL and an anticyclonic circulation on the eastern side. They also found that these rotating circulations are wind-driven, the former by the Tramontane, and the latter by the Mistral. The two rotating circulations join in the middle of the GoL, namely in the GAM.

HYGAM 1 observations and the corresponding modelling confirm these previous studies. We also show the consequences at the GAM scale. The origins of the south flux are better understood, and the consequence is an important temperature gradient $\left(>2{ }^{\circ} \mathrm{C}\right)$ between offshore and coastal waters (see Section 3.2. and Figs. 5 and 6). These warmer waters actually come from the $\mathrm{NC}$, warmer in winter than the surrounding waters, and particularly, warmer than the nearshore waters.

After the HYGAM 1 cruise, the model shows a persistence of the northward flux which splits into longshore drifts. The lateral drift toward southeast to east in the eastern part of the GAM is the only one to persist after 9 March. Then, until 20 March, the currents intensity is weak, corresponding to the weak winds intensity (see Section 3.1.). This period between the first two cruises favours also the first spring warmings (see Section 3.2.).

For the second cruise, the model results are less coherent with the data. Onshore the $70 \mathrm{~m}$-isobath, currents are globally longshore (they follow the isobaths) and westward (Fig. 7c). The model reproduces quite well this longshore flux (Fig. 7d). This flux might be explained by the sum of two effects. The first is due to the south winds with weak intensity $\left(\leqslant 4 \mathrm{~m} \mathrm{~s}^{-1}\right)$. These winds pile water on the shoreline and induce a raise of the sea surface elevation, estimated by the model to be $3-4 \mathrm{~cm}$ between the $70 \mathrm{~m}$ - isobath and the shoreline. Such a surface elevation slope is sufficient to create a geostrophic current on the order of $0.15-0.20 \mathrm{~m} \mathrm{~s}^{-1}$. The model proves that these longshore currents, in quasi-geostrophic equilibrium with the surface pressure gradient, can be accelerated by southeast winds which strengthen during the cruise. These simulated currents can reach $0.30 \mathrm{~m} \mathrm{~s}^{-1}$ (see Fig. 7d, latitude $43.3^{\circ} \mathrm{N}$, longitude $4.1^{\circ} \mathrm{E}$ ). Offshore of the $70 \mathrm{~m}$-isobath, the model is less coherent with the measurements.

Contrary to the HYGAM 1 cruise, in HYGAM 2 , the meteorological situation is less pronounced and fluctuates, leading to a more difficult analysis of the measured currents. Moreover, the model is less constrained by this type of inputs, and thus the model results can be less realistic. Although the meteorological conditions are very different from the first cruise, the south flux, which advects the warm waters in the GAM, is still observed, as shown during the first cruise (see Section 3.2).

During and after the HYGAM 2 cruise and until $28 \mathrm{March}$, the model exhibits the development of a strong westward nearshore drift (between 0 and $30 \mathrm{~m}$ isobaths). This drift can reach $0.60 \mathrm{~m} \mathrm{~s}^{-1}$ and is modelled during the HYGAM 2 cruise with an intensity of $0.30 \mathrm{~m} \mathrm{~s}^{-1}$. It is maintained by south to east atmospheric fluxes. This state changes completely in few hours on 28 March. North winds at the end of March create a circulation similar to the one described for the HYGAM 1 cruise. At the beginning of April, the south-southeastern winds again generate this strong westward nearshore drift. Before the HYGAM 3 cruise, the winds weaken, as well as the currents.

On 5 April, at the beginning of the HYGAM 3 cruise, the meteorological conditions are calm and the measured currents are weak $\left(<0.20 \mathrm{~m} \mathrm{~s}^{-1}\right.$ in Fig. 7e). The simulated currents at $16 \mathrm{~m}$ (Fig. $7 \mathrm{f}$ ) are coherent with the measured ones. As for HYGAM 2 cruise, the south-southeastern strong winds, preceding the cruise, piled the waters inside the gulf, creating a raise of the sea surface elevation on the order of $5 \mathrm{~cm}$ between the shoreline and the $90 \mathrm{~m}$ isobath. Thus, the westward currents parallel to the isobaths, which are both measured and reproduced by the model, might be part of the geostrophic equilibrium imposed by this slope.

\subsection{Concluding remarks on the hydrodynamics of the GAM}

This observation and modelling work at an intermediate scale between nearshore (e.g. Meulé et al., 2001) and coastal (e.g. Petrenko et al., 2005) studies is one of the first experiments for this region. It allows one to obtain a quite realistic description of the oceanic circulation during the 39 days of 
simulation, including the 6 days of observations. We note:

the important variability of the oceanic circulation at this scale,

the importance of the winds and of their horizontal gradients, inducing coherent structures, both at GAM and GoL scales,

the interactions with the general oceanic circulation (intrusions of the NC),

longshore currents achieving the geostrophic equilibrium with the surface slope, itself created by offshore winds,

important heat exchanges,

the formation of cold waters near the shoreline, certainly supplying the WIW,

advection of offshore warmer waters by northward surface flows,

potential (simulated but not measured) advection of nearshore colder waters by southward bottom flows.

\section{Applications}

In order to better understand the GAM hydrodynamics, many improvements need to be achieved, in modelling as well as in observation. However, this kind of realistic, qualified and validated simulation is useful to answer concrete questions asked by society. In the following, a concrete application is detailed (Section 4.1) and other future applications are considered (Section 4.2).

\subsection{Application to contaminant dispersion}

As mentioned in Section 1, the Montpellier sewage is dumped since 2005 by a pipeline located $10 \mathrm{~km}$ south of Palavas-Les-Flots, at a depth of $30 \mathrm{~m}$ (in the middle of the GAM, point S on Fig. 2). Its dispersion is a problem which needs a precise knowledge of the hydrodynamics.

Since it could be very complex to integrate biogeochemical reactions and no concentration data are available at the moment (because of a very recent implementation), we performed a very simple simulation based on the 39 days realistic simulation of hydrodynamics.

A simple advection-diffusion model (the same as those used for salinity or temperature) is used to simulate the $3 \mathrm{D}$ transport of a generic dissolved contaminant, whose concentration is noted $\mathrm{C}(X, t)$.
The contaminant used is not real, as a chemical specie (nitrate for example).

The unit of $\mathrm{C}(X, t)$ is expressed in $\mathrm{M} / \mathrm{V}$, a generic unit consistent with density in $\mathrm{kg} \mathrm{m}^{-3}$. A constant tendency $T \mathrm{C}_{0}=10^{-2}(\mathrm{M} / \mathrm{V}) \mathrm{s}^{-1}$ is imposed at point $\mathrm{S}$ (on the whole water column and for a $500 \times 500 \mathrm{~m}$ grid mesh) during the 39-day simulation. As the advection-diffusion equation of $\mathrm{C}(X, t)$ is linear relative to the $\mathrm{C}(X, t)$, all the results obtained for this generic contaminant can be extended by a simple proportionality rule. If $\mathrm{TN}_{0}$ is the real tendency of a real contaminant of concentration $\mathrm{N}(X, t)$, all the following results concerning $\mathrm{C}(X, t)$ can be extrapolated computing $\mathrm{N}(\mathrm{X}, \mathrm{t})=\left(\mathrm{TN}_{0} /\right.$ $\left.\mathrm{TC}_{0}\right) \mathrm{C}(\mathrm{X}, \mathrm{t})$.

Three arbitrary snapshots of surface concentrations are presented in Figs. 9a,c,e. The dates of these snapshots correspond to the dates of the HYGAM cruises and so, to the circulation sketches presented in Fig. 7. On 6 March (Fig. 9a), the dispersion is induced by the northward flux which splits into longshore drifts. On 21 March (Fig. 9c), there is a remaining plume to the North and a westward local advection on point S. On 5 April (Fig. 9e), the dispersion is toward southwest due to longshore currents. Looking at these snapshots as well as the analysis of the whole simulated results (not shown in the figures), the main remark is that there is a great variability of the dispersion sketches as there is a great variability of the currents at the GAM scale.

From this an arising question is to know if the coastal resorts are able to be contaminated. In order to address this issue, several time series of $\mathrm{C}(X, t)$ are shown on point S (Fig. 10a), at Sète (Fig. 10b), at Palavas-Les-Flots (Fig. 10c) and at La Grande Motte (Fig. 10d) (see locations in Fig. 2). The maximum value encountered on the shoreline is about $1.8 \mathrm{M} / \mathrm{V}$ on 3 April at Sète. This value is to be compared with the values obtained on the reject point S (Fig. 10a) which can reach $60 \mathrm{M} / \mathrm{V}$ (averaged on a $500 * 500 \mathrm{~m}$ grid mesh) for the midMarch period, when the winds (and currents) are weak (Fig. 3a) and the sewage is not very dispersed. As shown in Section 3.2, the great variability of the currents induced a great variability in these time series. It is possible to notice that a sampling frequency of at least 2 days is necessary to follow this variable.

This numerical application shows that the hydrodynamics at the GAM scale is an important control of the contamination hazards. This numerical application is, however, limited as there is no 
a

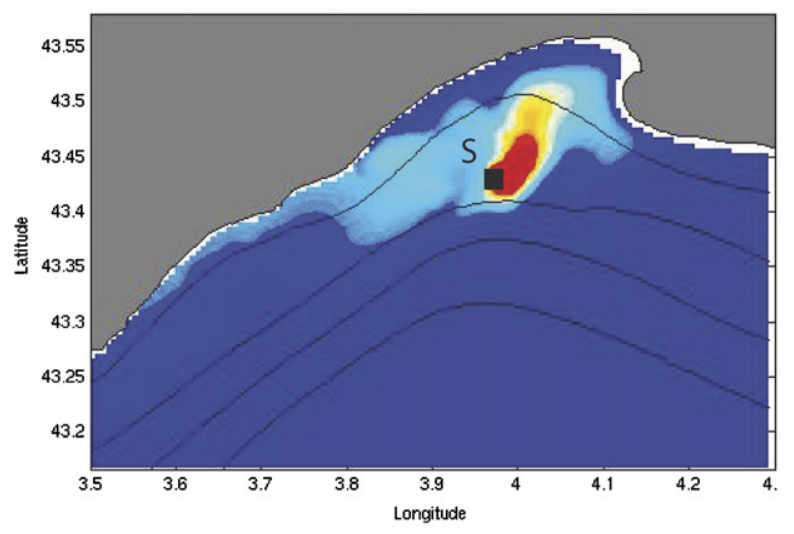

C

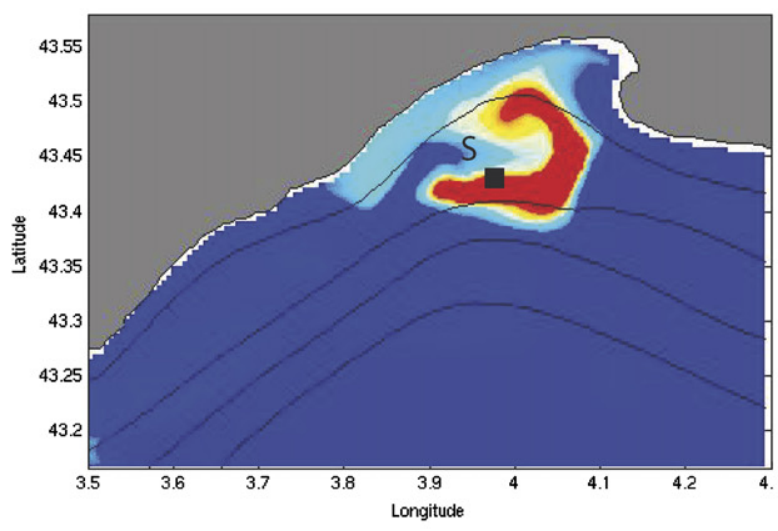

e

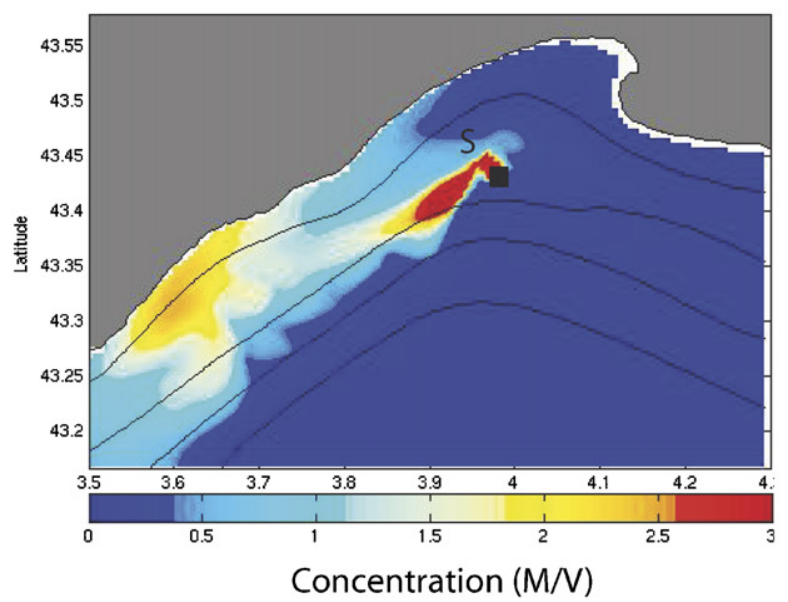

b

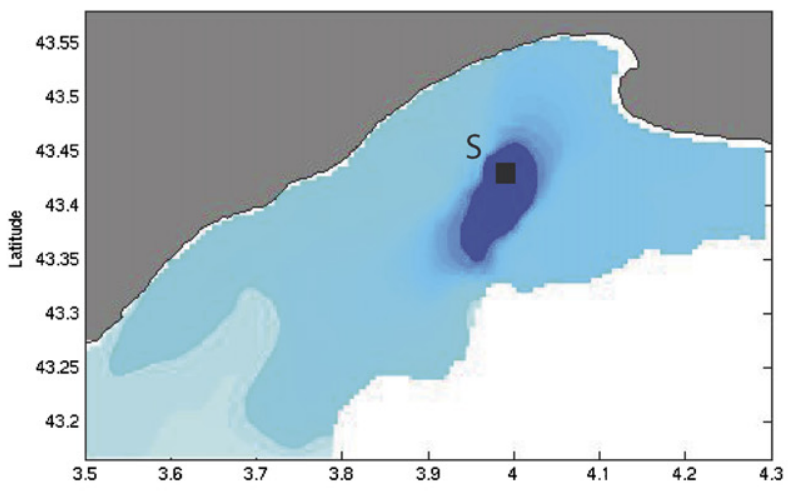

d

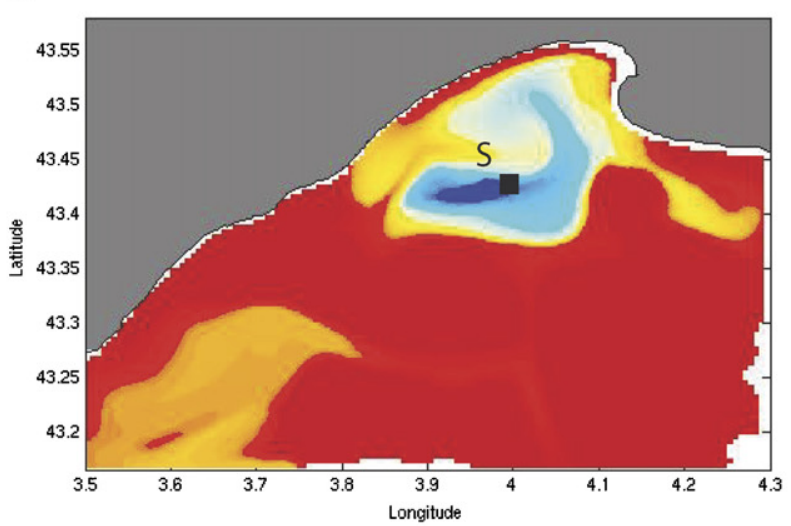

f

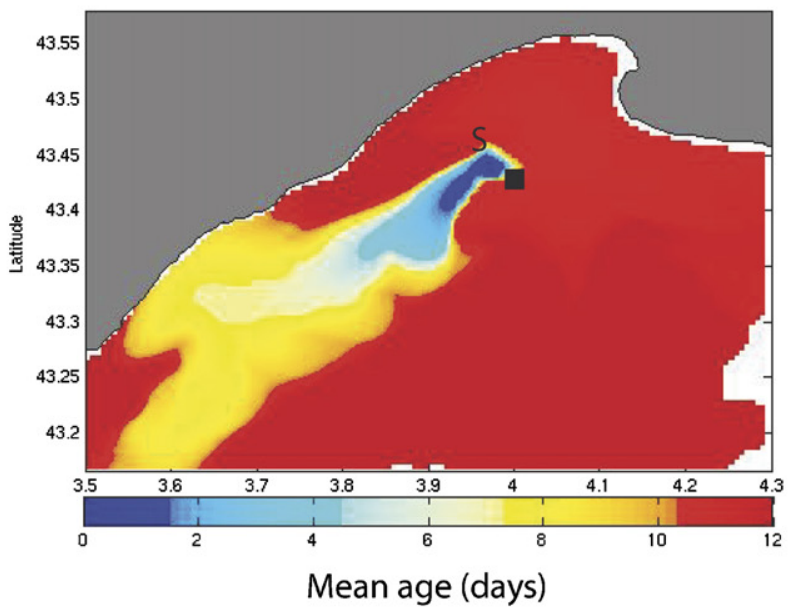

Fig. 9. (a) Surface concentration (colours, M/V) modelled at 12:00 h on 6 March. (b) Surface mean age (colours, days) modelled at 12:00 h on 6 March. (c) Surface concentration (colours, M/V) modelled at 06:00 h on 21 March. (d) Surface mean age (colours, days) modelled at 06:00 h on 21 March. (e) Surface concentration (colours, M/V) modelled at 12:00 h on 5 April. (f) Surface mean age (colours, days) modelled at 12:00 h on 5 April.

biogeochemical reactions included. It could be very complex to introduce degradation concepts and particular contaminants should be distinguished. At this stage, we choose to remain in a general case using the concept of the "age of a water parcel" defined by Delhez and Deleersnijder (2002) as "the 


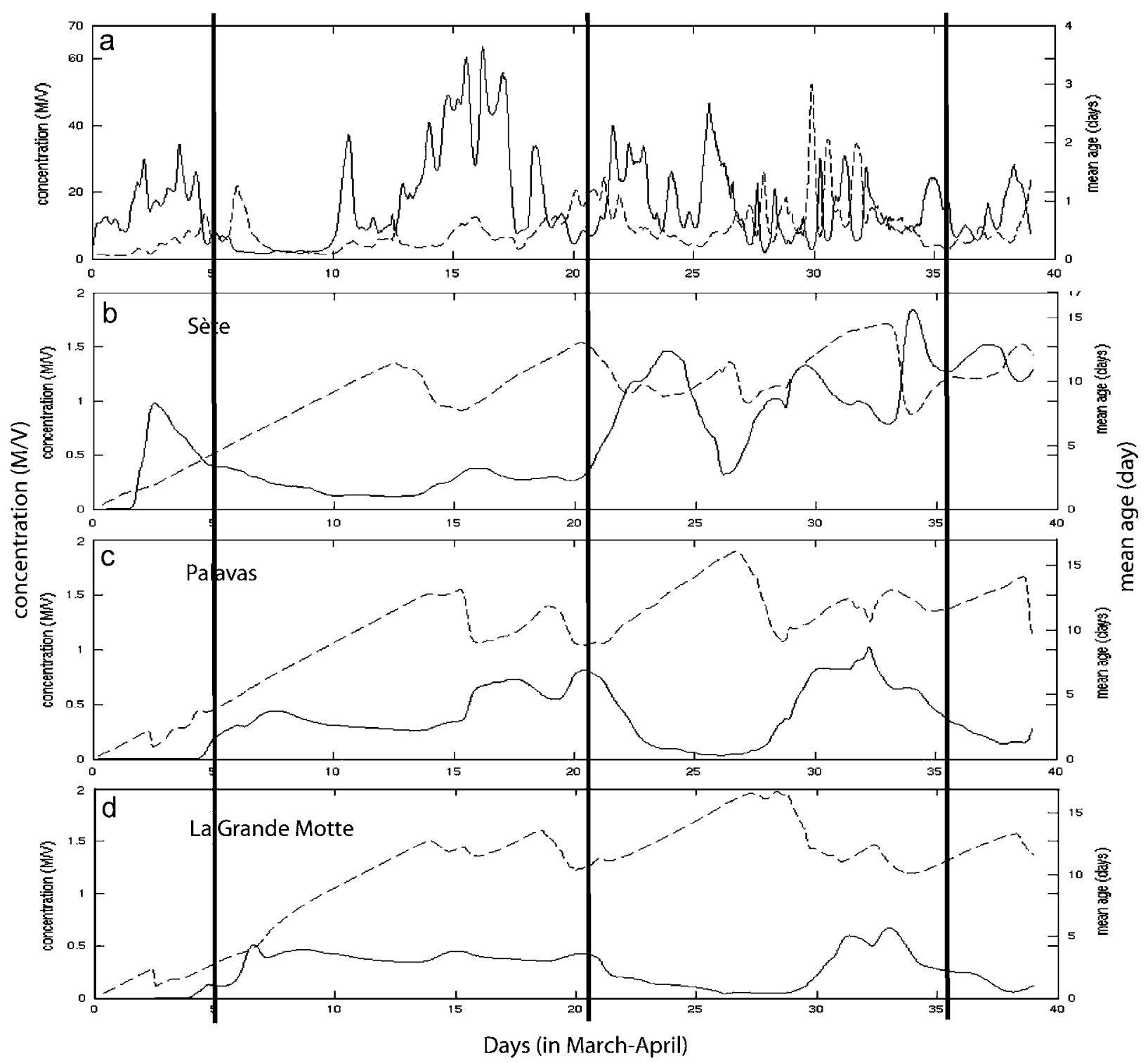

Fig. 10. Time series of surface concentration (solid lines and left axis) and mean age (dashed lines and right axis) at point S (a), at Sète (b), at Palavas-Les-Flots (c) and at La Grande Motte (d).

time elapsed since the parcel under consideration left the region in which its age is prescribed to zero". In our case, the age is prescribed to zero at the reject point S. Delhez et al. (1999) show how to compute the mean age noted $a(X, t)$ which in our case is the mean time elapsed since the contaminant was dumped at point S. $a(X, t)$ gives an insight of the available time for degradation. The computing of $a(X, t)$ is done via the so-called age concentration $\alpha(X, t)=a(X, t) \mathrm{C}(X, t)$. Delhez et al. (1999) show that $\alpha(X, t)$ follows the same advection-diffusion than $\mathrm{C}(X, t)$ with an extra production term which is
$\mathrm{C}(X, t)$ itself. This simple equation can be computed and $a(X, t)$, deduced.

The results of mean age simulation are presented as snapshots on Fig. 9 and as time series in Fig. 10 . Fig. 10 shows that the mean age is always under 2 days at the reject point $\mathrm{S}$ and can reach, without being over, 17 days on the shoreline. A contamination is potentially important not only when the concentration is strong, but also when the mean age, corresponding to an available time of degradation, is weak. For example, for the strongest concentration encountered on the shoreline $(1.8 \mathrm{M} / \mathrm{V}$ on 3 
April at Sète), the mean age is already 8 days. On the contrary, at the very beginning of the simulation, the concentration at Sète is only $1 \mathrm{M} / \mathrm{V}$ but the mean age is only 2 days.

Qualitatively, Palavas-Les-Flots and La Grande Motte are not touched by strong concentrations and for the maxima of concentration, the mean age remains rather high. For example, on 21 April, even if the plume is directed to the North (Fig. 9c), the mean age remains higher than 9 days on the shoreline (Fig. 9d). Sète is more directly touched, for example, on 5 April (Figs. 9e, 9f).

Quantitatively, this kind of simulation can be useful to compute contamination hazards for a particular contaminant, whose range of acceptable concentrations and kinematics of degradation are known.

\subsection{Future applications}

Other applications are numerous. The small coastal rivers, Mosson and Lez at Palavas-les-Flots, and Vidourle near La Grande-Motte (see locations in Fig. 2), also drain waters in urban and agricultural watersheds subject to contamination hazards. In the case of important floods, the rivers plumes are subject to the GAM hydrodynamics. As in the case of the sewage dispersion, the knowledge of the GAM hydrodynamics is then useful for computing the contamination hazards.

This hydrodynamics also plays an important role in the computation of the submersion and erosion hazards. The submersion events are known to occur in the region during the south to south-east storms. During these events, the setups induced by the winds, by the tides and by the swells cumulate. The offshore atmospheric fluxes also lead to important precipitations. The GAM coast is more often formed by beach ridges and low and lagoonar zones. These two factors aggravate the coastal submersion risks. For the submersion hazards computation, the numerical models have to integrate tide and swell effects.

Except for the Espiguette cape, near Port Camargue (see Fig. 2), the GAM coast is also subject to an intense erosion. The sand sedimentary transport study is usually done at the nearshore scale (e.g. Tessier et al., 2000; Meulé et al., 2001; Certain et al., 2005a, b). These studies consider the nearshore zone as a cell more or less isolated from offshore, with mainly longshore fluxes. It, however, seems important to evaluate cross-shore fluxes toward the offshore zone. Such fluxes certainly occur during south to east storms and might lead to sand lost beyond the coastal zone. This sand will then not contribute anymore to the coastal morphodynamics. To evaluate this flux, one will have to pursue studies such as the one presented in this paper, and more especially during storms.

In a region where tourism and coastal urbanisation impacts are fundamental, society expects tools to evaluate the hazards (contamination, erosion, or submersion). Scientific knowledge is then expected and this study is a first step.

\section{Acknowledgements}

The cruises and study were financed by the French National program PATOM. We are grateful to the crews of the Tethys II. We also thank JeanLuc Fuda and the Centre d'Océanologie de Marseille for the loan of the CTD probe, and Gilles Rougier, Julie Gatti, Pierre-Michel Theveny, Eric Berthebaud and Florent Lyard who participated in the $H Y G A M$ cruises.

\section{References}

Apel, J.R., 1987. Principles of Ocean Physics. International Geophysics Series, 38. Academic Press, New York, 634 pp.

Auclair, F., Estournel, C., Marsaleix, P., Pairaud, I., 2006. On coastal ocean embedded modeling. Geophysical Research Letters 33, L14602.

Blumberg, A. F., and Mellor, G. L., 1987. A description of a three-dimensional coastal ocean circulation model. In: Heaps, N., (Ed.), Three-Dimensional Coastal Ocean Models. American Geophysical Union, 208pp.

Canal, M., Puig, P., Durrieu de Madron, X., Heussner, S., Palanques, A., Fabres, J., 2006. Flushing submarine canyons. Nature 444, 16.

Certain, R., Tessier, B., Barusseau, J.-P., Courp, T., Pauc, H., 2005a. Sedimentary balance and sand stock availability along a littoral system. The case of the western Gulf of Lions littoral prism (France) investigated by very high resolution seismic. Marine and Petroleum Geology 22 (6-7), 889-900.

Certain, R., Meulé, S., Rey, V., Pinazo, C., 2005b. Wave transformation on a microtidal barred beach (Sète, France). Journal of Marine Systems 58 (1-2), 19-34.

Conan, P., Millot, C., 1995. Variability of the NC off Marseilles, western Mediterranean Sea, from February to June 1992. Oceanologica Acta 18 (2), 193-205.

Delleville, S., 1997. Contribution à la modélisation de la dynamique marine d'été du golfe du Lion. Application d'un modèle emboité passif. Thèse, Université d'Aix-Marseille II.

Dufau-Julliand, C., Marsaleix, P., Petrenko, A., Dekeyser, I., 2004. Three-dimensional modeling of the Gulf of Lion's hydrodynamics (northwest Mediterranean) during January 1999 (MOOGLI3 Experiment) and late winter 1999: Western 
Mediterranean Intermediate Water's (WIW's) formation and its cascading over the shelf break. Journal of Geophysical Research 109, C11002.

Durrieu de Madron, X., Radakovitch, O., Heussner, S., LoyePilot, M.D., Monaco, A., 1999. Role of the climatological and current variability on shelf-slope exchanges of particulate matter: Evidence from the Rhône continental margin (NW Mediterranean). Deep-Sea Research 46, 1513-1538.

Echevin, V., Crépon, M., Mortier, L., 2003. Interaction of a coastal current with a gulf application to the shelf circulation of the Gulf of Lions in the Mediterranean Sea. Journal of Physical Oceanography 33, 188-206.

Estournel, C., Kondrachoff, V., Marsaleix, P., Vehil, R., 1997. The plume of the Rhone: numerical simulation and remote sensing. Continental Shelf Research 17 (8), 899-924.

Estournel, C., Durrieu de Madron, X., Marsaleix, P., Auclair, F., Julliand, C., Vehil, R., 2003. Observation and modelisation of the winter coastal oceanic circulation in the Gulf of Lions under wind conditions influenced by the continental orography (FETCH experiment). Journal of Geophysical Research 108 (C3), 8059.

Estournel, C., Zervakis, V., Marsaleix, P., Papadopoulos, A., Auclair, F., Perivoliotis, L., Tragou, E., 2005. Dense water formation and cascading in the Gulf of Thermaikos (North Aegean) from observations and modelling. Continental Shelf Research 25, 2366-2386.

Flather, R.A., 1976. A tidal model of the northwest European continental shelf. Mémoire de la Société Royale des Sciences de Liege, Series 6 (10), 141-164.

Gaspar, P., Gregoris, Y., Lefevre, J.M., 1990. A simple eddy kinetic energy model for simulations of the oceanic vertical mixing tests at station Papa and long-term upper ocean study site. Journal of Geophysical Research 95, 179-193.

Gatti, J., Petrenko, A., Devenon, J.L., Leredde, Y., 2005. Intrusions of the Mediterranean Northern Current on the eastern side of the Gulf of Lion's continental shelf, NW Mediterranean Sea. Geophysical Research Abstracts 7, 00986.

Lamy, A., Millot, C., Molines, J.M., 1981. Bottom pressure and sea level measurements in the Gulf of Lions. Journal of Physical Oceanography 11 (3), 394-410.

Lapouyade, A., Durrieu de Madron, X., 2001. Seasonal variability of the advective transport of particulate matter and associated organic carbon in the Gulf of Lions (NW Mediterranean). Oceanologica Acta 24, 295-312.
Marsaleix, P., Auclair, F., Estournel, C., 2006. Considerations on open boundary conditions for regional and coastal ocean models. Journal of Atmospheric and Oceanic Technology 23, 1604-1613.

Meulé, S., Pinazo, C., Degiovanni, C., Barusseau, J.-P., Maurice, L., 2001. Numerical study of sedimentary impact of a storm on a sand beach simulated by hydrodynamic and sedimentary models. Oceanologica Acta 24 (5), 417-424.

Millot, C., 1990. The Gulf of Lion's hydrodynamics. Continental Shelf Research 10 (9-11), 885-894.

Monaco, A., Courp, T., Heussner, S., Carbonne, J., Fowler, S.W., Deniaux, B., 1990. Seasonality and composition of particulate fluxes during ECOMARGE-I, western Gulf of Lions. Continental Shelf Research 10 (9-11), 959-987.

Naudin, J.J., Cauwet, G., Fajon, C., Oriol, L., Terzic, S., Devenon, J.L., Broche, P., 2001. Effect of mixing on microbial communities in the Rhone River Plume. Journal of Marine Systems 28, 203-227.

Petrenko, A., Leredde, Y., Marsaleix, P., 2005. Circulation in a stratified and wind-forced Gulf of Lions, NW Mediterranean Sea: in-situ and modeling data. Continental Shelf Research 25, 7-27.

Raimbault, P., Durrieu de Madron, X., 2003. Research activities in the Gulf of Lion (NW Mediterranean) within the 1997-2001 PNEC project. Oceanologica Acta 26, 291-298.

Shchepetkin, A.F., McWilliams, J.C., 2005. The regional oceanic modeling system (ROMS): A split-explicit, free-surface, topography-following-coordinate oceanic model. Ocean Modelling 9, 347-404.

Tessier, B., Certain, R., Barusseau, J-P., Henriet, J.P., 2000. Évolution historique du prisme littoral de l'étang de Thau (Sète, Sud-Est de la France). Mise en évidence par sismique réflexion THR, C. R. Acad. Sci. Paris, Sciences de la Terre et des planètes/ Earth and Planetary Sciences 331, pp. 709-716.

Ulses, C., Grenz, C., Marsaleix, P., Schaaff, E., Estournel, C., Meulé, S., Pinazo, C., 2005. Circulation in a semi-enclosed bay under influence of strong freshwater input. Journal of Marine Systems 56 (1-2), 113-132.

Zodiatis, G., Lardner, R., Georgiou, G., Demirov, E., Pinardi, N., Manzella, G., 2003. The Cyprus coastal ocean forecasting and observing system, a key component in the growing network of European ocean observing systems. Sea Techno$\operatorname{logy} 44$ (10), 10-15. 